\title{
HUBUNGAN PENGETAHUAN DAN SIKAP DENGAN PERILAKU PENCEGAHAN COVID-19 PADA SISWA DI SMPN 13 PESAWARAN
}

\author{
Achmad Farich ${ }^{1}$, Wahid Tri Wahyudi2*, Chelda Ernita ${ }^{3}$
}

\author{
1Dosen Program Studi Ilmu Keperawatan Universitas Malahayati \\ Email: farichrich@gmail.com \\ 2Dosen Program Studi Ilmu Keperawatan Universitas Malahayati \\ Email: nisun.yudi@yahoo.com \\ ${ }^{3}$ Mahasiswa Program Studi Ilmu Keperawatan Universitas Malahayati \\ Email: cheldaernita37@gmail.com
}

\section{ABSTRACT: RELATIONSHIP OF KNOWLEDGE AND ATTITUDE WITH COVID-19 PREVENTION BEHAVIOR IN STUDENTS AT SMPN 13 PESAWARAN}

Introduction: Based on observations made on offline students (outside the network) it was found that there were students who did not understand, obey and apply health protocols at school. It was found (39.7\%) of students did not comply with the health protocol outside the supervision of the teacher, such as not bringing a mask to school, not keeping the distance between friends, and still having students touching the face area.

Objective: It is known how the relationship between knowledge and attitudes with Covid-19 prevention behavior in students at SMPN 13 Pesawaran.

Methods: This research uses quantitative research with observational analytic methods, namely research that tries to understand the relationship between variables by analyzing the data that has been obtained. The research design used is a cross-sectional design to determine the relationship between knowledge and attitudes with COVID-19 prevention behavior in offline students at State Junior High School (SMP N) 13 Pesawaran.

Results: Statistical test of knowledge using chi-square, obtained P-Value 0.000 so that $P$-Value $(0.0<0.5)$ then there is a relationship with the value of Odds Ratio 9.8 attitude statistic test using chi-square, obtained P-Value 0.01 so $P$ Value $(0.1<0.5)$ then there is a relationship with the value of Odds Ratio 8.

Conclusions and suggestions: Students of SMPN 13 Pesawaran have less than optimal knowledge and attitudes accompanied by less than optimal behavior in preventing Covid-19. To further improve supervision of school residents so that they always comply with health protocols to break the transmission line of Covid-19.

Keywords: Knowledge, Attitude, Covid-19 Prevention Behavior 


\section{INTISARI: HUBUNGAN PENGETAHUAN DAN SIKAP DENGAN PERILAKU PENCEGAHAN COVID-19 PADA SISWA DI SMPN 13 PESAWARAN}

Pendahuluan: Berdasarkan pengamatan yang dilakukan pada siswa luring (luar jaringan)ditemukan adanya siswa yang belum memahami, mematuhi dan menerapkan protokol kesehatan disekolah. Ditemukan $(39,7 \%)$ siswa yang tidak mematuhi protokol kesehatan diluar pengawasan guru seperti tidak membawa masker saat kesekolah, tidak menjaga jarak antar teman dan masih adanya siswa yang menyentuh area wajah.

Tujuan: Diketahui bagaimana hubungan pengetahuan dan sikap dengan perilaku pencegahan Covid-19 Pada Siswa Di SMPN 13 Pesawaran.

Metode: Penelitian menggunakan jenis penelitian kuantitaif dengan metode analitik observasional, yaitu penelitian yang mencoba memahami hubungan antar variable dengan menganalisis data yang telah diperoleh. Desain penelitian yang digunakan yaitu desain cross-sectional untuk mengetahui hubungan antara pengetahuan dan sikap dengan perilaku pencegahan COVID-19 pada siswa yang luring di Sekolah Menengah Pertama Negeri (SMP N) 13 Pesawaran.

Hasil: Uji statistik pengetahuan menggunakan chi-square, didapat P-Value 0.000 sehingga $P$-Value a $(0.0<0.5)$ maka terdapat hubungan dengan nilai Oods Ratio 9.8 uji statistik sikap menggunakan chi-square, didapat $P$-Value 0.01 sehingga $P$ Value a $(0.1<0.5)$ maka terdapat hubungan dengan nilai Oods Ratio 8.

Kesimpulan dan saran: Siswa SMPN 13 Pesawaran memiliki pengetahuan dan sikap yang kurang optimal diiringi dengan perilaku yang kurang optimal dalam pencegahan Covid-19. Agar bisa lebih meningkatkan pengawasan pada warga sekolah agar selalu mematuhi protokol kesehatan agar dapat memutus tali penularan Covid-19.

Kata Kunci: Pengetahuan, Sikap, Perilaku Pencegahan Covid-19

\section{PENDAHULUAN}

Coronavirus 2019 (Covid-19) merupakan jenis penyakit baru yang belum pernah terdeteksi pada manusia sebelumnya. Virus penyebab Covid-19 disebut Sars-CoV2. Kasus Covid-19 yang parah dapat menyebabkan pneumonia, sindrom pernapasan akut, gagal ginjal serta kematian (Kementrian Kesehatan Republik Indonesia, 2020; Handayani, 2020)

Cara efektif untuk mencegah Covid-19 adalah dengan menggunakan hand sanitizer untuk kebersihan tangan. Jika tangan anda tidak terlalu kotor, atau jika tangan anda terlihat kotor, cuci tangan dengan sabun, hindari menyentuh mata, hidung dan praktikkan etika batuk atau bersin gunakan bagian dalam lengan atau tisu untuk menutupi hidung dan mulut, lalu letakkan tisu ke tempat sampah. Jika mengalami gejala pernapasan, mohon kenakan masker. Setelah membuang masker, bersihkan tangan dan jaga jarak tertentu (minimal 1 meter) dari orang yang mengalami gejala pernafasan (Kementrian Kesehatan Republik Indonesia, 2020; Marzuki, 2021)

Berdasarkan data global terkait perkembangan Covid-19 (data dilaporkan sampai 04 Februari 2021), terdapat $103,989,900$ data global yang terkonfirmasi, 2,260,259 kematian di 222 negara tertular, dan 185 kasus terkonfirmasi data Negara yang terkait kasus tertinggi transmisi lokal adalah Amerika Serikat, India, Brazil, Rusia, Britania Raya, Perancis, Italia, Turki, Jerman 
(Kementrian Kesehatan Republik Indonesia, 2021).

Berdasarkan data Covid-19 di Indonesia, jumlah orang yang diperiksa sebanyak 6,322,350, terkonfirmasi Covid-19 sebanyak $1,123,105$, dengan sembuh (positif Covid-19) sebanyak 917,036, dengan meninggal (positif Covid-19) sebanyak 31,001 , dan data negative Covid-19 sebanyak 5,199,245. Dengan data kasus konfirmasi tertinggi di Provinsi Indonesia DKI Jakarta, Jawa Barat, Jawa Tengah, Jawa Timur, Sulawesi Selatan, Kalimantan Timur, Riau, Sumatera Barat, Bali, dan Banten (Kementrian Kesehatan Republik Indonesia, 2021).

Berdasarkan data terkait Covid-19 di Provinsi Lampung dengan data 18 maret 2020 kamis - 4 februari 2021 pukul 10.00 WIB. Dengan data kasus suspek total sebanyak 250, kasus baru sebanyak 40, dan kasus lama sebanyak 210. Total kasus terkonfirmasi dengan total 10.543 dengan kasus baru sebanyak 98, kasus lama 10445. Dengan konfirmasi kematian sebanyak 553 dan selesai isolasi terkonfirmasi sebanyak 8092 . Sedangkan berdasarkan data covid19 di Pesawaran pada tanggal 4 februari yaitu suspek sebanyak 11 orang, probable sebanyak 9 orang, kasus terkonfirmasi sebanyak 458 orang, selesai isolasi sebanyak 335 orang dan kasus meninggal sebanyak 19 orang serta masuk ke dalam resiko kenaikan kasus pada resiko sedang (bewarna orange) (Dinas Kesehatan Provinsi Lampung, 2021). Menjaga

kesehatan dipengaruhi oleh 2 faktor utama, yaitu perilaku dan non-perilaku. Perilaku ditentukan oleh tiga faktor yaitu, faktor predisposisi yaitu pengetahuan, sikap, kepercayaan, keyakinan, nilai-nilai, faktor pemungkin yaitu lingkungi fisik, fasilitas ataupun sarana kesehatan, faktor pendorong yaitu sikap serta perilaku petugas kesehatan (Notoatmodjo, 2014; Pertiwi, 2020). Berdasarkan pengamatan (observasi) yang dilakukan pada siswa dalam pembelajaran luring ditemukan masih adanya siswa yang belum memahami, mematuhi dan menerapkan protokol kesehatan disekolah. Ditemukan adanya $(39,7 \%)$ siswa yang tidak mematuhi protokol kesehatan diluar pengawasan guru seperti, tidak membawa masker saat ke sekolah, tidak menjaga jarak antar teman dan masih adanya siswa yang menyentuh area wajah.

Berdasarkan masalah tersebut diatas maka peneliti tertarik untuk meneliti lebih jauh mengenai hubungan pengetahuan dan sikap dengan perilaku pencegahan covid19 pada siswa di SMPN 13 Pesawaran.

\section{METODOLOGI PENELITIAN}

Jenis penelitian kuantitatif dengan metode analitik observasional dan pendekatan cross sectional. Populasi dalam penelitian ini adalah siswa luring SMPN 13 Pesawaran. Jumlah sampel dalam penelitian ini sebanyak 63 siswa, teknik sampling yang digunakan adalah dengan cara teknik total sampling. Penelitian ini telah dilakukan Tanggal 6 April - 21 April 2021 di SMPN 3 Pesawaran. Peneliti menggunakan analisa data univariat dan bivariate menggunakan uji chi-square. Peneliti mendapatkan ijin komite etik penelitian dari universitas malahayatai dengan nomor : 1686/EC/KEP-UNMAL/V/2021 pada tanggal 26 Maret 2021.

Alat ukur/instrument berupa kuesioner peneliti menggunakan kuesioner yang sudah pernah dilakukan uji validitas dan reliabilitas, sehingga peneliti tidak melakukan uji validitas dan reliabilitas lagi. Instrument yang digunakan merupakan instrument 
dari penelitian : Muhammad Dezha Detiro (2020) Hubungan Antara Pengetahuan dan Sikap Terhadap Perilaku Pencegahan Covid-19 Pada Mahasiswa Kedokteran di Provinsi Aceh, menyebutkan bahwa hasil penelitian menunjukan baha sebanyk $54,1 \%$ responden memiliki pengetahuan baik, $73,1 \%$ responden memiliki sikap yang baik, $46,6 \%$ responden memiliki perilaku pencegahan yang baik serta terdapat hubungan yang lemah namun berarti antara pengetahuan $(r=0,214$, $\mathrm{p}=0,000$ ) dengan perilaku pencegahan Covid-19 dan hubungan yang cukup bermakna antara sikap $(r=0,477, p=0,000)$ terhadap perilaku pencegahan Covid-19.

\section{HASIL DAN PEMBAHASAN}

Analisa Unvariat

Distribusi Frekuensi Pengetahuan, Sikap, Perilaku Pada Siswa dengan Pencegahan COVID-19 Di SMP Negeri 13 Pesawaran $(\mathrm{N}=63)$

\begin{tabular}{ccc} 
Pengetahuan & Frekuensi & Persentase (\%) \\
\hline Kurang baik & 46 & $73.0 \%$ \\
\hline Baik & 17 & $27.0 \%$ \\
\hline Total & 63 & $100 \%$ \\
\hline Sikap & Frekuensi & Persentase (\%) \\
\hline Kurang baik & 55 & $87.3 \%$ \\
\hline Baik & 8 & $12.7 \%$ \\
\hline Total & 63 & $100 \%$ \\
\hline Perilaku & Frekuensi & Persentase (\%) \\
\hline Kurang baik & 42 & $66.7 \%$ \\
\hline Baik & 21 & $33.3 \%$ \\
\hline Total & 63 & $100 \%$
\end{tabular}

Berdasarkan tabel diketahui bahwa pada variable pengetahuan siswa dapat diketahui bahwa responden yang memiliki pengetahuan kurang yaitu 46 responden $(73.0 \%)$. Sedangkan, jumlah responden yang memiliki pengetahuan baik yaitu 17 responden (27.0\%).

Berdasarkan tabel diketahui bahwa pada variable sikap siswa dapat diketahui bahwa responden yang memiliki sikap kurang baik yaitu 55 responden (87.3\%).Sedangkan, jumlah responden yang memiliki sikap baik yaitu 8 responden $(12.7$ $\%)$.

Berdasarkan tabel diketahui bahwa pada variable perilaku siswa dapat diketahui bahwa responden yang memiliki perilaku kurang baik yaitu 42 responden (66.7\%). Sedangkan, jumlah responden yang memiliki perilaku baik yaitu 21 responden (33.3\%). 
Hubungan Pengetahuan Dengan Perilaku Pencegahan Covid-19 Pada Siswa Di SMP Negeri 13 Pesawaran

\begin{tabular}{|c|c|c|c|c|c|c|c|}
\hline \multirow{3}{*}{ Pengetahuan } & \multicolumn{4}{|c|}{$\begin{array}{c}\text { Perilaku Pencegahan } \\
\text { COVID-19 }\end{array}$} & \multirow{3}{*}{$\begin{array}{l}\text { Total } \\
\mathrm{N}\end{array}$} & \multirow{3}{*}{$\begin{array}{c}\text { P- } \\
\text { Value }\end{array}$} & \multirow{3}{*}{ OR } \\
\hline & \multicolumn{2}{|c|}{ Kurang baik } & \multicolumn{2}{|r|}{ Baik } & & & \\
\hline & $\mathrm{N}$ & $\%$ & $\mathrm{~N}$ & $\%$ & & & \\
\hline Kurang baik & 37 & 80.4 & 9 & 19.6 & 46 & 0.000 & 9.867 \\
\hline Baik & 5 & 29.4 & 12 & 70.6 & 17 & & (2.764 - \\
\hline Total & 42 & 66.7 & 21 & 33.3 & 63 & & 35.219) \\
\hline
\end{tabular}

Berdasarkan menunjukkan bahwa dari 46 responden yang memiliki pengetahuan kurang baik, 37 responden $(80.4 \%)$ dikategorikan kurang baik dalam menerapkan perilaku pencegahan COVID-19 dan 9 responden (19.6\%) menerapkan pengetahuan baik. Sedangkan dari 17 responden yang memiliki pengetahuan baik, 5 responden (29.4\%) kurang baik dalam menerapkan pengetahuan dan 12 responden (70.6\%) dalam menerapkan pengetahuan baik.
Hasil analisis menggunakan chisquare, didapat $P$-Value $=0.000$ sehingga $P$-Value $<\mathrm{a} \quad(0.00<0.05)$ maka HO ditolak. Jadi dapat disimpulkan terdapat hubungan pengetahuan dengan perilaku pencegahan COVID-19 di SMP Negeri 13 Pesawaran. Dari hasil analisis diperoleh pula nilai Oods Ratio 9.8, pada siswa dengan pengetahuan kurang baik beresiko 9.8 kali lebih besar mengalami perilaku pencegahan Covid-19 kurang baik dibandingkan dengan pengetahuan baik.

\section{Hubungan Sikap Dengan Perilaku Pencegahan Covid-19 Pada Siswa Di SMP Negeri 13 Pesawaran}

\begin{tabular}{|c|c|c|c|c|c|c|c|}
\hline \multirow{3}{*}{ Sikap } & \multicolumn{4}{|c|}{$\begin{array}{c}\text { Perilaku Pencegahan } \\
\text { COVID-19 }\end{array}$} & \multirow[b]{2}{*}{ Total } & \multirow{3}{*}{ P-Value } & \multirow[b]{2}{*}{ OR } \\
\hline & \multicolumn{2}{|c|}{ Kurang baik } & \multicolumn{2}{|c|}{ Baik } & & & \\
\hline & $\mathrm{N}$ & $\%$ & $\mathrm{~N}$ & $\%$ & $\mathrm{~N}$ & & \\
\hline Kurang baik & 40 & 72.7 & 15 & 27.3 & 55 & 0.013 & 8.000 \\
\hline Baik & 2 & 25.0 & 6 & 75.0 & 8 & & (1.452 - \\
\hline Total & 42 & 66.7 & 21 & 33.3 & 63 & & 44.090) \\
\hline
\end{tabular}


Berdasarkan tabel menunjukkan bahwa dari 55 responden yang memiliki sikap kurang baik, 40 responden $(\mathbf{7 2 . 7 \% )}$ dikategorikan kurang baik dalam menerapkan perilaku pencegahan COVID-19 dan 15 responden (27.3\%) menerapkan sikap baik. Sedangkan dari 8 responden yang memiliki sikap baik, 2 responden $(25.0 \%)$ kurang baik dalam menerapkan sikap dan 6 responden $\quad(75.0 \%)$ dalam menerapkan sikap baik. Hasil analisis menggunakan chi-square, didapat $\mathrm{P}$ Value $=0.013$ sehingga $P$-Value $<a$ $(0,01<0,05)$ maka HO ditolak. Jadi dapat disimpulkan terdapat hubungan sikap dengan perilaku pencegahan COVID-19 di SMP Negeri 13 Pesawaran. Dari hasil analisis diperoleh pula nilai Oods Ratio 8, pada siswa dengan sikap kurang baik beresiko 8 kali lebih besar mengalami perilaku pencegahan Covid-19 kurang baik di bandingkan dengan siswa yang memiliki sikap baik.

\section{Hubungan pengetahuan dengan perilaku pencegahan covid-19 pada sisa di SMPN 13 Pesawaran}

Hasil analisis menggunakan chisquare, didapat $P$-Value $=0.000$ sehingga $P$-Value $<\mathrm{a} \quad(0.00<0.05)$ maka HO ditolak. Jadi dapat disimpulkan terdapat hubungan pengetahuan dengan perilaku pencegahan COVID-19 di SMP Negeri 13 Pesawaran. Dari hasil analisis diperoleh pula nilai Oods Ratio 9.8, pada siswa dengan pengetahuan kurang baik beresiko 9.8 kali lebih besar mengalami perilaku pencegahan Covid-19 kurang baik dibandingkan dengan pengetahuan baik.

Penelitian ini sejalan dengan penelitian (Detiro, 2020) tentang Hubungan Antara Pengetahuan dan Sikap Terhadap Perilaku Pencegahan Covid-19 Pada Mahasiswa Kedokteran di Provinsi Aceh, menyebutkan bahwa hasil penelitian menunjukan baha sebanyk $54.1 \%$ responden memiliki pengetahuan baik, $73.1 \%$ responden memiliki sikap yang baik, $46.6 \%$ responden memiliki perilaku pencegahan yang baik serta terdapat hubungan yang lemah namun berarti antara pengetahuan $(r=0.214, \quad p=0.000)$ dengan perilaku pencegahan COVID19 dan hubungan yang cukup bermakna antara sikap ( $r=0.477$, $\mathrm{p}=0.000$ ) terhadap perilaku pencegahan Covid-19.

Hasil analisa peneliti bahwa terdapat siswa pengetahuan baik namun perilaku kurang baik, sesuai dengan teori (Notoatmodjo, 2014; Zulaiha, 2020) bahwa pengetahuan yang baik dapat terjadi karena pengetahuan seseorang didapat dari panca indranya seperti melihat suatu objek. Tetapi pengetahuan baik belum tentu selarasa dengan perilaku baik melainkan perilaku kurang baik. Pengetahuan baik tetapi perilaku kurang baik karena sebelum memasuki ke tahap perilaku, seseorang harus memiliki sikap dahulu, sesuai dengan (Dewi, 2016; Octavia, S. A, 2020; Rahmat, 2021; Purandina, 2020) sikap terdiri dari beberapa faktor yang mempengaruhinya salah satunya yaitu faktor kepercayaan. Jika seseorang tidak mempercayai adanya virus Covid-19, maka ia tidak akan berperilaku baik dalam pencegahan Covid-19 sehingga menimbulkan perilaku kurang baik. Sedangkan, pengetahuan kurang baik tetapi perilaku baik hal tersebut terjadi karena adanya sikap individu dalam tingkatan menerima yang artinya siswa dengan pengetahuan kurang baik dapat berperilaku baik karena adanya ketentuan dari pihak sekolah untuk berperilaku mematuhi protokol kesehatan pencegahan Covid-19, hal tersebut didukung dengan adanya tingkatan sikap yang siswa ambil yaitu tingkatan 
menerima artinya bahwa orang atau subjek mau menerima stimulus yang diberikan (objek) sesuai dengan teori (Notoatmodjo, 2014; Jumiati, 2018; Mahardhani, 2020; Ramadhani, 2020)

\section{Hubungan Sikap Siswa Dengan Perilaku Pencegahan COVID-19 di SMP Negeri 13 Pesawaran}

Hasil penelitian yang dilaukan pada siswa di SMP Negeri 13 Pesawaran dapat diketahui bahwa besarnya signifikasi adalah p-value 0.01 (0.01< $0.05)$. Hasil ini menjawab hipotesis bahwa apabila tingkat signifikan $<0.05$ maka Ho ditolak. Maka, hasil terseubt dapat dinyatakan bahwa ada hubungan sikap dengan perilaku pencegahan COVID-19 di SMP Negeri 13 Pesawaran.Dikarenakan mayoritas siswa memiliki pengetahuan yang kurang baik sehingga dapat mempengaruhi sikap pada setiap siswa dalam perilaku pencegahan Covid-19. Namun terdapat faktor lain yang mempengaruhi sikap seperti argument atau pendapat siswa sebelumnya sehingga dapat mempengaruhi sikap siswa tersebut. Terdapat hasil analisis diperoleh pula nilai Oods Ratio 8 artinya responden dengan sikap baik mempunyai resiko 8 untuk menghasilkan perilaku pencegahan Covid-19 tidak baik.

Penelitian ini sejalan dengan penelitian (Ray, 2021) tentang Hubungan Antara Pengetahuan, Sikap, dan Perilaku Masyarakat Terhadap Pencegahan Pandemi COVID-19 di Kota Tanjung Balai, menyebutkan bahwa hasil penelitian menunjukan pada pengetahuan $=0.0001 \quad(<0.05)$, nilai $p$ value pada sikap $=0.0001(0.05)$, dan nilai $p$ value pada perilaku $=0.0001(<0.05)$, sehingga terdapat hubungan pengetahuan, sikap, dan perilaku masyarakat terhadap pencegahan pandemic Covid-19 di Tanjung Bali.
Didapat hasil analisa peneliti bahwa terdapat siswa dengan sikap yang baik tetapi perilaku kurang baik terjadi karena terdapat faktor pemungkin yang sesuai dengan teori (Notoatmodjo, 2014; Syakurah, 2020; Rosidin, 2020) yaitu lingkungan fisik. Jika lingkungan fisik tidak mendukung dalam berperilaku baik dalam mematuhi protokol kesehatan pencegahan Covid-19, maka akan berpengaruh perilaku kurang baik. Sedangkan sikap kurang baik tetapi perilaku baik dapat terjadi karena adanya tingkatan sikap yang sesuai dengan teori (Notoatmodjo, 2014; Lathifah, 2021) yaitu tingakatan sikap menghargai artinya seseorang memberikan nilai positif terhadap objek atau stimulus bahan mengajak atau mempengaruhi seseorang untuk merespon, hal sikap tersebut ditunjjukan oleh guru sehingga mempengaruhi siswa yang memiliki sikap kurang baik dapat berperilaku baik dalam pencegahan Covid-19.

\section{KESIMPULAN}

Diketahui dari 63 responden dengan pengetahuan kurang baik sebanyak 46 (73\%) responden, sebanyak 55 $(87,3 \%)$ responden sikap kurang baik, sebanyak $55 \quad(12,7 \%)$ responden perilaku kurang baik, ada hubungan pengetahuan dengan perilaku pencegahan Covid-19 pada siswa dan ada hubungan sikap dengan perilaku pencegahan Covid-19 pada siswa di SMPN 13 Pesawaran. 
DAFTAR PUSTAKA

Andini, $\quad$ N. P. P. P. (2021). GAMBARAN SIKAP PENCEGAHAN COVID-19 MASYARAKAT DI DESA BELUMBANG KECAMATAN KERAMBITAN KABUPATEN TABANAN TAHUN 2021 (Doctoral dissertation, Poltekkes Kemenkes Denpasar).

Detiro, M. D. (2020). Hubungan Antara Pengetahuan dan Sikap Terhadap Perilaku Pencegahan COVID-19 Pada Mahasiswa Kedokteran di Provinsi Aceh. https://etd.unsyiah.ac.id/in dex.php?p=show_detail\&id=8 5785

Dewi, W. A. dan M. (2016). Teori dan Pengukuran PENGETAHUAN, SIKAP DAN PERILAKU MANUSIA (Cetakan II). Nuha Medika.

Dinas Kesehatan Provinsi Lampung. (2021). Situasi Terkini Perkembangan COVID-19 05 Februari 2021. https: / /dinkes.lampungprov. go.id/tag/covid-19/

Handayani, R. T., Arradini, D., Darmayanti, A. T., Widiyanto, A., \& Atmojo, J. T. (2020). Pandemic Covid19, Body Immunity Response, and Herd Immunity. Jurnal Ilmiah Permas: Jurnal Ilmiah STIKES Kendal, 10(3), 373380.

Jumiati, I. (2018). PENGARUH PENDIDIKAN KESEHATAN TERHADAP PENGETAHUAN DAN SIKAP BULLYING PADA SISWA DI SD NEGERI 01 NGESREP KECAMATAN BANYUMANIK KOTA SEMARANG (Doctoral dissertation, Universitas Muhammadiyah Semarang).

Kementerian Kesehatan Republik Indonesia; Gerakan
Masyarakat Hidup Sehat. (2020). Apa Yang Harus Dilakukan Masyarakat Untuk Cegah Penularan Covid-19. 2020, 1-24. https: / / promkes.kemkes.go. id/download/enjn/files 8654 8Pedoman apa yang harus dilakukan-CEGAH-COVID19.pdf

Kementrian Kesehatan Republik Indonesia. (2020). Pedoman Pencegahan dan Pengendalian Coronavirus Disease (COVID-19). Germas. https: / www.google.com/ur l?sa=t\&source=web\&rct $=$ j\&ur l=https: / /infeksiemerging.k emkes.go.id/download/REV04_Pedoman P2_COVID19_27_Maret2020_TTD1.pdf \&ved $=2 a h U K E$ wiYrfzt5afuAh XXT30KHVMFAzoQFjABegQIC RAB\&usg=AOVVawOY1nwXnL WOf8EYFuaA451z\&cshid $=161$ 1052411794

Kementrian Kesehatan Republik Indonesia. (2021). Situasi Terkini Perkembangan Coronavirus Disease (COVID19) 05 Februari 2021. https://infeksiemerging.ke mkes.go.id/situasi-infeksiemerging/situasi-terkiniperkembangan-coronavirusdisease-covid-19-05februari-2021

Lathifah, H. (2021). upaya guru pai dalam meningkatkan motivasi belajar siswa pada pembelajaran daring di smpn 1 geger madiun (Doctoral dissertation, PONOROGO).

Mahardhani, A. J., \& KP, M. (2020). Menjadi Warga Negara yang Baik pada Masa Pandemi Covid-19: Persprektif Kenormalan Baru. JPK (Jurnal Pancasila dan Kewarganegaraan), 5(2), 6576. 
Marzuki, I., Bachtiar, E., Zuhriyatun, F., Purba, A. M. V., Kurniasih, H., Purba, D. H., ... \& Airlangga, E. (2021). COVID19: Seribu Satu Wajah. Yayasan Kita Menulis

Mukarom, Z. (2020). Teori-Teori Komunikasi.

Notoatmodjo, S. (2014). IImu Perilaku Kesehatan. PT Rineka Cipta.

Ray, V. N. M., Samion, M., \& Lukito, A. (2021). Hubungan Antara Pengetahuan, Sikap, dan Perilaku Masyarakat Terhadap Pencegahan Pandemi COVID-19 di Kota Tanjung Balai. IV(I), 39-45. https://www.ojsfkuisu.com/ index.php/stm/article/view $\underline{170}$

Octavia, S. A. (2020). Motivasi belajar dalam perkembangan remaja. Deepublish

Pertiwi, A., \& Sunarti, S. (2018). Hubungan Tingkat Pengetahuan Ibu dengan Perilaku Pijat Balita di PUSKESMAS Kecamatan Marangkayu Kabupaten Kutai Kartanegara.

Purandina, I. P. Y. (2020). Pendidikan Karakter Tumbuh Selama Pandemi Covid19. COVID-19: Perspektif Pendidikan, 99.

ahmat, P. S. (2021). Perkembangan peserta didik. Bumi Aksara.

Zulaiha, D., \& Rohman, A. (2020). Strategi Guru dan Keterlibatan Orangtua dalam Pemahaman Konsep Sains Anak Selama Covid-19. Jurnal Obsesi: Jurnal Pendidikan Anak Usia Dini, (2), 12481260. Ramadhani, F., \& Nuryani, N. (2020). Knowledge Have Correlation with Preventive Practice Covid-19 in College Students of Gorontalo. Jurnal Ilmiah Kesehatan, 2(3), 108-117.

Rosidin, U., Rahayuwati, L., \& Herawati, E. (2020). Perilaku dan peran tokoh masyarakat dalam pencegahan dan penanggulangan pandemi covid-19 di Desa Jayaraga, Kabupaten Garut. Umbara, 5(1), 42-50.

Syakurah, R. A., \& Moudy, J. (2020). Pengetahuan terkait usaha pencegahan Coronavirus Disease (COVID-19) di Indonesia. HIGEIA (Journal of Public Health Research and Development), 4(3), 333-343 